\title{
5 Where is Alexandria?
}

The dream that was once planted into the consciousness of the city, will haunt it like a restless ghost, until it either takes material shape and returns to life, or this dream comes to an end and dies, or a new dream is invented.

Alaa Khaled, Alexandrian Faces

There are thus very likeable myths which are however not innocent.

Roland Barthes, Mythologies

\section{The Chinese Housing}

In March 2015, on one of my many journeys between Berlin and Alexandria, I landed at Borg El Arab airport west of Alexandria late at night. The airport is 50 $\mathrm{km}$ away from the city centre, but close to many thriving industrial areas, holiday villages, and up-market suburbs that have been built west of the city and on the North Coast in the past two decades. They are part of a general scheme by the Egyptian government to create new cities far from the old urban centres.

At the airport, I was picked up by my friend M., whom I have known since the days when he was still living in his native village in the northern Nile Delta. He has been living half an hour from the airport in the district of Agami on the western edge of Alexandria since 2009. Agami is known among the Egyptian bourgeoisie as a pleasant, traditional, and (formerly) exclusive beach resort (Abdel Gabbar 2013). M., however, lives $3 \mathrm{~km}$ away from the coast in an informally built area on a small hill right behind the Chinese Housing (al-Masakin al-Siniya), a neighbourhood of large public housing blocks. The area was built in the 1980s as company housing for public-sector companies by an Egyptian-Chinese joint venture.

For decades, the Chinese Housing was an area where poor and marginalised people lived, people who lacked the means to build a house of their own in an informal settlement. It had experienced periods of gang wars that forced the inhabitants to stay indoors for up to three days. Meanwhile, though, the neighbourhood had become calmer and the population more mixed. M. and I moved through the area with no sense of risk even late at night.

Two years earlier, an Egyptian employee at a foreign research institute in Alexandria had been shocked to hear that I frequented the Chinese Housing. She said that she was surprised I was still alive. For her it was a no-go area, definitely 
not part of her city. If anything, it was an anti-city neighbourhood that marked the boundaries of and threatened a bourgeois Alexandria, a cosmopolitan seaside city.

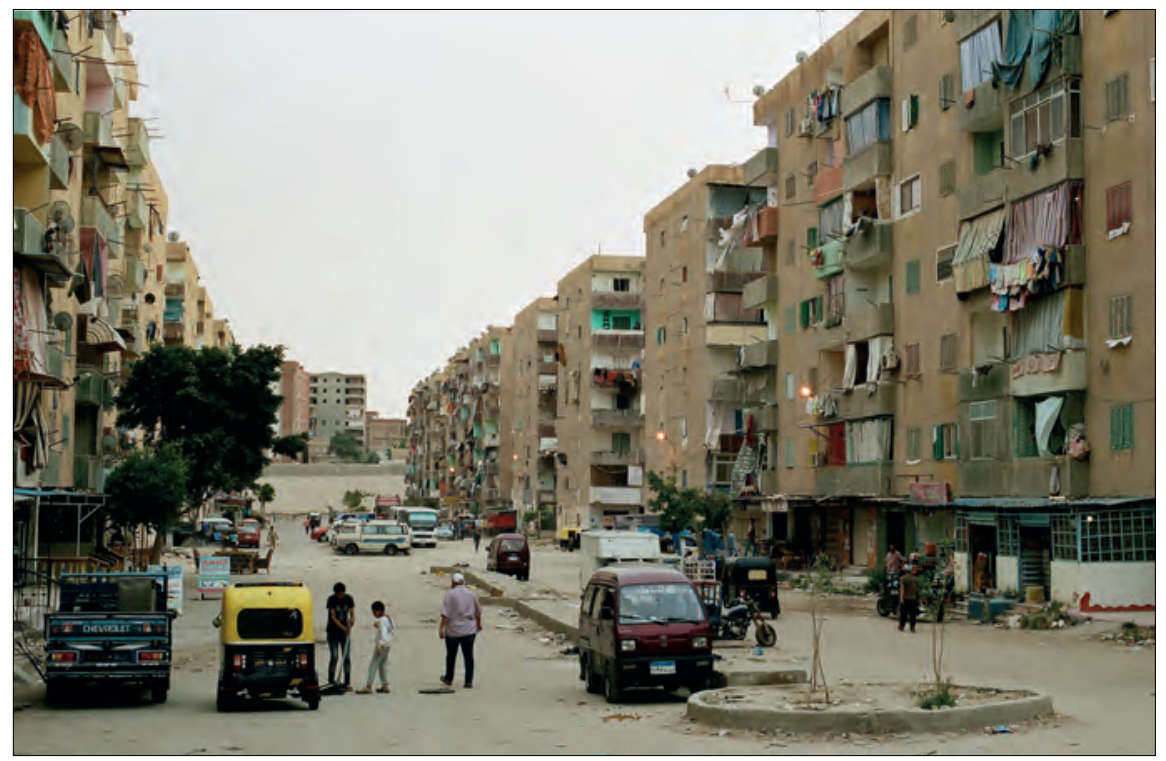

Image 16: The Chinese Housing, April 2016.

The next evening, I continued my journey on a minibus to the opposite end of the city, the neighbourhood of El Mandara in the east. El Mandara is where I lived during my stays in Alexandria as Mukhtar's guest until 2017. To avoid the congested roads along the seafront, the minibus took a detour inland via the International Road that crosses Lake Maryutiya on a landfill bridge, where the nauseating smell of pollution occasionally compels passengers to hold their noses. The road passed poor informal areas in inland Agami, the upmarket suburb of King Marriot, vast chemical and cement factory complexes, and the upmarket City Center shopping mall (not near the historical centre of the city). Finally, the minibus entered the city again along 45 Street, in what is known as the East of the City (Sharq al-madina). Approaching the end of the line, the minibus turned into smaller streets, passed the Faculty of Islamic Studies of the al-Azhar University, and finally entered busy Mallaha Street surrounded by shops, market stands, and congested by private cars, taxis, minibuses, and toktoks.

Eastern Alexandria is symbolically divided classwise by the Abu Qir suburban train line, the seaside being generally more well off and the inland being mostly poorer. I got out at a spot where this mythological division is a tangible 
reality: at a minibus stop next to the railway line. On the other, wealthier side of the railway were the Muntazah Gardens (formerly the royal summer residence, now a public park), the Fathallah shopping mall, the Sheraton, and the beach. On the side I was on, the informal area of inland El Mandara began: construction has been ongoing since the 1990s, with fifteen-storey houses replacing older fivestorey ones.

In Mukhtar's words, this is 'the ugly face of Alexandria'. It would indeed be difficult to find the Chinese Housing, the International Road, or inland El Mandara beautiful in any conventional sense. It is not simply the poor face of the city, however. The suburban crescent that surrounds the old coastal core of Alexandria is made up of poor, middle-income, and upmarket neighbourhoods alike. They provide homes and work for millions, and yet none of these would count as the real Alexandria in the media, literary, and scholarly accounts of the city - and many of the inhabitants of the suburban crescent would agree. When I asked M. what the real Alexandria is for him, he did not name the Chinese Housing where he lives, but rather the popular quarter of Bahary in the ancient centre of the city, his favourite site for outings with his family. Where, then, is Alexandria?

Alexandria has a reputation for being cosmopolitan - or having once been so, in a past belle époque when Europeans dominated the bourgeois districts of the city. That era is gone, but the reputation and romance of Alexandria live on. Western readers are likely to know Alexandria from the works of Greek, British, and other European writers who lived in the city, or more specifically in the European-dominated central districts of the city that still carry the material memory of that era. Readers of those works will remain largely ignorant, however, of the vast majority of the city's inhabitants, Arabic-speaking Egyptians, and of the neighbourhoods they inhabited. Arabic literature on Alexandria is only gradually finding its way into the canon of Alexandrian cosmopolitanism (see Hazem 2006; Kararah 2006; Starr 2009; Halim 2013). Historians and literary scholars have provided textured accounts that question the Eurocentrism of the myth of cosmopolitan Alexandria (Fahmy 2006; Zubaida 2011: 131-155; Halim 2013; Chiti 2016; Hanley 2017). And yet an ambiguous nostalgia for a bygone cosmopolitan era is also shared by many Arabic-speaking inhabitants of Alexandria today, in a time when the city has left that era behind and something rather different is emerging in a sweeping movement of urban erasure and expansion.

In this chapter, I trace a selection of contemporary afterlives of the myth of Alexandria as something different and better than the city that actually exists. The result is part ethnography of one specific literary milieu and part urban ethnography, where writers from that milieu provide the main theoretical inspiration. Which old and new myths of the city, I ask in conversation with them, are being crafted, questioned, or revised in such a moment, and what might they tell 
us about the wider imagined and material locations of the city? How do specific neighbourhoods figure in those myths? What political and moral claims about the city are involved in them?

Questions about the city arose repeatedly and persistently during our fieldwork with writers in Alexandria. The city is a major theme for many of them, indeed one of the most important themes that we encountered. Some contemporary literary accounts of the city are fairly well known nationally and internationally, such as Ibrahim Abdel Meguid's (1999, 2005, 2013) Alexandria Trilogy and Alaa Khaled's (2012) literary work as well as his ongoing editorship of the journal Amkenah since 1990. There are many others who are less prominent but not less interesting. In the following, I engage with a handful of writers of the latter kind. All of them were at the time of the research more or less involved in the small, internationally connected and funded independent or avant-garde scene in the city, a scene that is open to the world but limited in its societal reach (see Chapter 2).

When such cosmopolitan circles become the breeding ground for an intellectual critique of nostalgia for the cosmopolitan, something important is going on. Equally important is the historical moment in which such a critique emerged: the aftermath of the 25 January revolution, which despite its political defeat transformed both the way many young writers and intellectuals see the world and city they live in, and the material shape of the city itself. It has since 2011 been subjected to rapid erasure and reconstruction in the course of a construction boom.

In this chapter, I work with concepts and ideas that I have encountered in my fieldwork, and consider them as theories that may provide valid answers to the inquiry. I nevertheless call those theories myths because that is the form in which they circulate: as narrative, dramatic structures that may be told in different words (Lévi-Strauss 1955), and that naturalise moral and political claims and relations of power (Barthes 1970).

In his literary exploration of Alexandria, Alaa Khaled evokes the dreaminess of an Alexandria haunted by its myths - but also points out that those myths may change along with the city:

The dream that was once planted into the consciousness of the city will haunt it like a restless ghost, until it either takes material shape and returns to life, or this dream comes to an end and dies, or a new dream is invented. (Khaled 2012: 20)

Myths thus understood are compelling narrative structures that are to be judged by their power to inspire one to think and act along the lines they suggest. They have historical, political, and social lives worthy of attention (Chiti 2016), which means they are never separate from struggles and relations of power, as pointed 
out by Roland Barthes (1970: 72): 'There are thus very likeable dreams which are however not innocent.' Following on from Khaled's, Chiti's, and Barthes' insights about the historicity and complicity of myths, I add that, when considered as social theories, some myths may also be better suited to providing guidance in a given reality than others.

Despite being highly mythologised, contemporary Alexandria is a rather ordinary city (El Chazli 2018), and its recent development is not remarkably different from so many other cities in the Global South that, in a short time, have transformed into vast conglomerates that have little in common with the cities they once may have been (AlSayyad and Roy 2005; Robinson 2006; Simone and Pieterse 2017). The nostalgia for a past colonial-cosmopolitan era is also a common feature of cities in the Global South (Bissell 2005; Newcomb 2017).

As Setrag Manoukian (2012) shows in his work on the Iranian city of Shiraz, talking about a city always involves highlighting some of its districts and neighbourhoods, and silencing others. Myths that purport to reveal a city's true location and values need to account for those locations and values that don't fit into the story: neighbourhoods and ways of living that are marked as not legitimately part of the mythologised city. I call them the anti-city. When I speak about 'the city' in the following, it is thus within the tension between the urban conglomerate that is too large for a textured account, my specific knowledge of some parts of it, and various myths that tell us what and where that conglomerate really is and ought to be - as well as what it is not and ought not to be.

\section{Cyprus}

For M., the real Alexandria is the old popular neighbourhood of Bahary, located at the tip of the peninsula where the historic centre of Alexandria lies. He knows Bahary inside out because many of the wholesale and retail shops in his trade are located in the narrow alleys of the neighbourhood. With its old bourgeois houses on the seaside facing the picturesque Eastern Harbour crowded by small boats, it is also a place where he enjoys taking a stroll with his family once or twice a year. In contrast, the Egyptian-Australian political scientist Amro Ali who has written much about the city in recent years (Ali 2010-2019), described in conversation with me the early twentieth-century bourgeois neighbourhoods of Camp Caesar, Ibrahimiya, Cleopatra, and Sidi Gaber a few kilometres further east as being for him the heart of Alexandria. Between these two areas lie the districts of Raml Station and al-Manshiya, which form the once European-dominated historical downtown (wust al-balad) of the city. This is today characterised by popular 
cafés, lively shopping streets, and shoppers and flâneurs strolling in squares and streets that still bear the visible mark of bygone eras (Khaled 2012). For many writers and others who gather in the cafés located here, this is Alexandria proper. Holiday visitors from Cairo and the Nile Delta, in turn, spread along the more than $10 \mathrm{~km}$ long Corniche Road that follows the seashore - or, if they can afford them, the beaches of Agami and Mamoura further to the west and east, respectively. For them, that is Alexandria.

Whenever I ask people where the 'real Alexandria' is located for them, I typically get seaside replies. They differ in terms of class (as between M. and Amro Ali) and in terms of interests (between literati and summer guests), but there is wide agreement about the shore of the Mediterranean being Alexandria's proper location. And yet over the past hundred years, the city's inland links have proved more enduring.

Founded by Alexander the Great in 331 BCE, Alexandria today bears few visible traces of its long history. Contemporary Alexandria is a child of the trade expansion and industrial revolution of the late nineteenth and early twentieth centuries. Its rapidly growing population was mainly made up of migrants from upper Egypt, Nubia, and the nearby countryside, along with large numbers of European and Ottoman subjects who moved there. Alexandria of the colonial era was also a city of many inequalities marked by lines of nationality and class (Hanley 2017), and it could only last as long as the privileged position of foreign nationals lasted. Following the 1956 Suez Crisis, most Egyptian Jews as well as French and British citizens were forced to leave. The already dwindling Greek and Italian communities were allowed to stay, but the majority of their members gradually emigrated following the socialist nationalisation policies of the $1960 \mathrm{~s}$ (Kazamias 2009). Alexandria became a city dominated by Arabic-speaking Egyptians of Muslim or Christian faith. They or their ancestors were once newcomers to the city, too, having arrived as rural to urban migrants in the city and having gone on to reproduce the plurality of Egypt within it.

The novelist Abdelfattah Morsi (see Chapter 3) argued in a conversation in 2014 that Alexandria is a city of recent arrivals: 'Those who arrived on the morning train claim to be the original Alexandrians towards those who arrived on the afternoon train.' A city 'left by the foreigners as a clean table for Egyptians to take over', Abdelfattah Morsi's Alexandria is a rootless conglomerate of individual lives without an authentic traditional society. For him, it is a city one cannot write about in the way Naguib Mahfouz wrote about Cairo.

And people keep arriving: rural to urban migrants and commuters, refugees from Syria and Libya, students from across the world studying at the Islamic al-Azhar university, Egyptian, Arab, and fewer Asian and Western tourists. But that mixture does not strike Western visitors and journalists as cosmopolitan. In 
Alexandria, 'cosmopolitanism' is usually equated with urban coexistence across religious and ethnic lines, but not all coexistence counts. Alexandria's cosmopolitanism is mainly equated with Europeans and European-dominated quarters. ${ }^{1}$ This Eurocentrism is notably reproduced in the way 'cosmopolitanism' is used in Arabic as a French/English loan word, kuzmubulitaniyya, although the concept would be easily translatable into Arabic (Raouf 2016).

No wonder, then, that anything that happened after the 1950s hardly counts in standard accounts of the city's assumed cosmopolitanism. Towards the end of the twentieth century, a new transformation of the city began, caused by rapid urbanisation and real estate development. Today, the most populous parts of Alexandria are no longer the old central districts, but the numerous new areas that have grown to the east, south, and west of the city. With few exceptions, the villas and small houses that once stood near the seafront to the east and west of central Alexandria have been demolished and replaced by high-rise buildings.

While the Alexandria of the seafront, with its Euro-cosmopolitan past, has been associated with holiday romance and images of a liberal Egypt open to the world, inland Alexandria has become known as a centre of Islamist activism since the 1970s. By the early 2000s, the purity-oriented Salafi movement became a main religious player in the city, competing with the Muslim Brotherhood for followers (Decschamps-Laporte 2014). The ahistorical vision of Salafism resonates well with the drive of real estate developers to demolish and build. Notably, both Salafism and real estate speculation are truly global movements for which national borders and identities are secondary. And yet, just like rural migrants and Syrian refugees, Salafis and real estate speculators also do not fit into the standard narrative of Alexandria's cosmopolitanism. The seaside cosmopolitan myth is a story of past grandeur and present decline, in which the contemporary city is not worthy of interest in its own right. Outside Egypt, it has been reproduced by concerned journalists (Traub 2014; Hadid 2016) as well as critical intellectuals - including Edward Said (2000) who, in a remarkable suspension of his otherwise critical perceptiveness, romanticised the privileged lifestyles of Alexandria's cosmopolitan upper classes.

It is not just foreign visitors who are drawn to such romantic melancholia, however. At a time when both twentieth-century secularist nationalist visions of a bright future as well as the material and cultural continuity of the twentieth-

1 While many historians tend to avoid the Eurocentric pitfall, recent historiography of Ottoman cities (e.g. Freitag and Lafi 2014) also tends to equate cosmopolitanism with the well-ordered urban coexistence of different ethnic and religious groups, and not with border-crossing lives or a sense of worldliness that would amount to 'citizenship of the world' of one sort or another. 
century city were beginning to crumble, a new interest in cosmopolitan Alexandria before the 1950s emerged. Cultural circles in the city developed an increasing interest in non-Arabic heritage. Both Egyptian state institutions and international cultural organisations and funding bodies began to actively promote a usually depoliticised and sanitised vision of past glory. This vision is today also supported by social media pages that post photos of colonial, monarchy-era, and early republican Egypt, often accompanied by explicit words of praise for a beautiful past and denigration of the present (Ryzova 2014, Elsherif forthcoming).

Nostalgia is a way to critique the present by comparing it with an idealised past (Boym 2001). It can promote different interests and have different undertones of appreciation and critique. Government promotion of the cosmopolitan narrative goes hand in hand with a neglect, even rejection, of old urban centres in favour of new satellite cities in urban planning policies. For the state and its investor allies, a vague cosmopolitan nostalgia appears to be a useful sales pitch for the aggressive erasure of existing structures of urbanity. Liberal members of the urban bourgeoisie I have met often feel that a city that once was theirs has been taken from them by uncultured, backward, and fundamentalist rural migrants. For them, nostalgia for a glorified past is a claim to restore their domination. The nostalgia I have encountered among non-bourgeois Alexandrians, in contrast, has less to do with values and more to do with the loss of access to the sea and public spaces, congestion, and the disappearance of old neighbourhood structures. In any case, most of those who today marvel at the past beauty of the city only know its glorified past from media, books, and stories. This paradox is pointed out by Abdelrehim Youssef in a poem he wrote in 2003:

Beautiful Alexandria

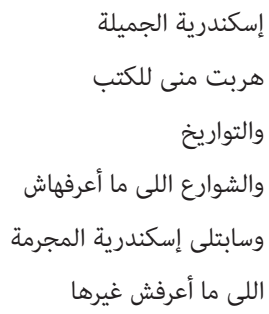

escaped me into books

and histories

and streets I don't know

and left me with criminal Alexandria

the only one I know

(Youssef 2003; my translation) 
And yet, no matter how counterfactual it may be today, the idealised association of Alexandria with beauty needs to be taken seriously as something that many inhabitants of the city strive for.

Regardless of their political and religious views, their origin and their class position, inhabitants of the city generally appreciate the sea, even if they only rarely manage to take a stroll along the seafront in their free time. On warm evenings, the Corniche becomes crowded with families, couples, groups of friends, and lone strollers. Many of them sit down and look out on the sea, towards the lights that can be seen on the horizon. I have been told that they are the lights of Cyprus.

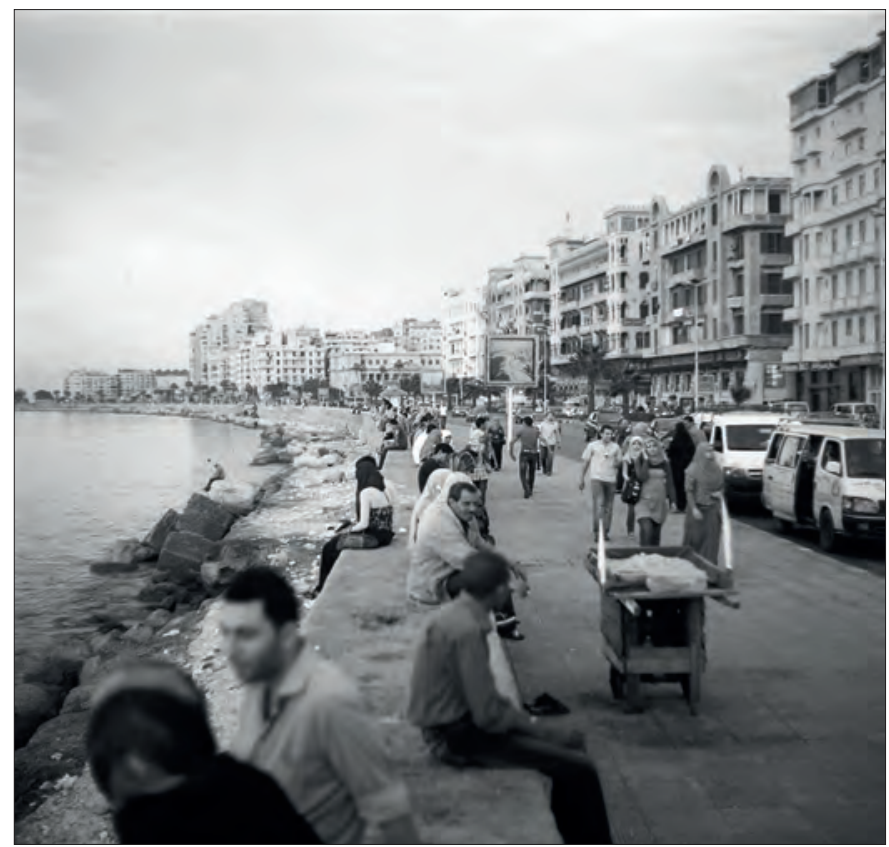

Image 17: The seafront by Raml Station, October 2011.

Unromantic sceptics object that it is impossible to actually see Cyprus because it is more than $500 \mathrm{~km}$ away from Alexandria, and that the lights on the horizon belong to ships and fishing boats. I am not interested in whether it really is Cyprus they see. Instead, I am interested in the gaze itself of the night-time strollers as they look at the dim lights on the horizon. That gaze says something about the city's paradoxical location between a congested, segregated, and largely unappealing urban conglomerate stretching inland - where the vast majority of its inhabitants live and work - and the seaside as the mythological, value-laden location of the city where inhabitants and visitors can imagine and appreciate 
Alexandria as something beautiful and magical, even if they only rarely manage to actually go there. The Cyprus seen by those strolling on the Corniche is an intimate part of Alexandria. Rather than firmly locating Alexandria as part of the Mediterranean world, however, the gaze toward Cyprus highlights the ambiguity of the Mediterranean Sea, having become a border that divides more than it is a means of communication that unites.

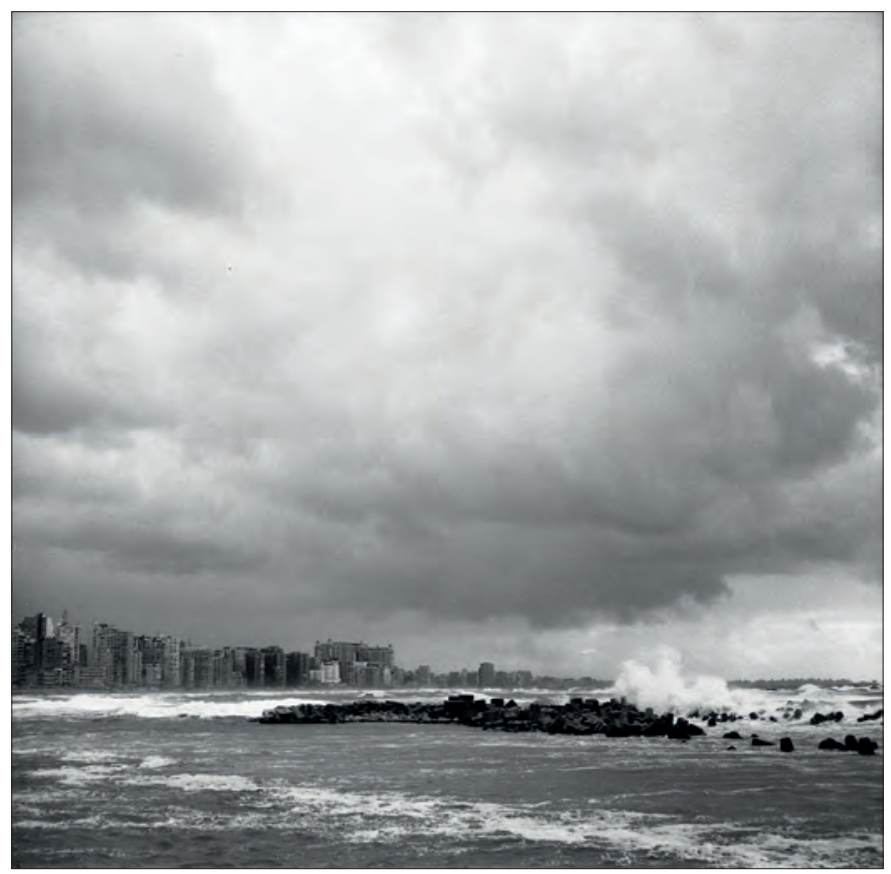

Image 18: The Mediterranean Sea during a winter storm, Miami, Alexandria, February 2012.

As a city mythologically located on the sea, Alexandria is also defined by the presence of borders right in its urban heart. The international border of the Mediterranean Sea is paralleled by the class boundaries that run between seaside and inland neighbourhoods, and between the many segregated suburbs even further inland. Those borders, in turn, establish the stranger or the Other as a key figure in the myths that can be told about the city. Explaining what and where Alexandria is typically involves some narration of the relationships of strangeness and alterity that structure the city and the specific spots where those relationships evolve - be they romanticised, as the 'cosmopolitan era' and the historical downtown that still embodies its memory often are, or scandalised, as the anti-city of the sub-urban crescent often is. 
What makes literature interesting as a production site of such myths is that it often creates myths with a twist, myths that try to change the setup of the stories worth telling.

\section{Ghurbal}

This is the Alexandria into which the lawyer and poet Hamdy Zidan was born in 1972: the neighbourhood of Ghurbal, south-west of the historical downtown, one of Alexandria's old 'popular districts' (ahya' sha 'biya). His grandparents migrated to Alexandria from Upper Egypt in the first half of the twentieth century and settled there. His father was a wedding singer, and Hamdy became interested in literature and music at an early age. He describes the Ghurbal of his youth as his key inspiration, a society that was at once conservative and open-minded. It is a densely populated quarter of narrow streets laid out in a modernist quadratic grid. In his childhood, the houses had only two floors built of brick and a third floor built of tinplate and wood. Several families shared one floor or one apartment, with a shared kitchen and bathroom. Christians and Muslims, people from different parts of the country, all lived together. With the houses fully packed, life took place in the streets. According to Hamdy, there was a magic to the streets, paved with basalt blocks, with steps of iron and stone pillars: 'This quarter creates drama and debate. The place gave me the magic key to language.'

Hamdy enrolled at the university in 1990, weeks after Saddam Hussein's occupation of Kuwait, and shortly before the collapse of the Soviet Union. It was a time when the great ideas of socialism and Arab nationalism that had inspired so many writers and intellectuals were being shattered. At around this time, he became active in a literary circle that published the short-lived literary magazine Khamasin, which promoted a literary aesthetic that was close to daily life and language, and departed from the complex symbolism and ideological commitments of the preceding generation. Hamdy says that Khamasin carried the mark of the historical moment of shattered utopias. Enjoying 'the joy of detail', writing in simple style about ordinary topics,

we saw that art is not an answer but a way to pose questions. The writer is not the original creator (mubdi) of the literary work. Instead, he discovers the poetic condition ( $h a l)$ in the streets. We did it in face of an established literature that had become bureaucratic not only in its institutions but also in style. We were not trying to save the world, but to save the self.

In the 1990s, Alexandria's literary life depended largely on the network of staterun cultural centres spread across the city. Conservative and avant-garde writers 
gathered in the same places. In around 2000, a new, 'independent' scene began to emerge in quarters close to downtown Alexandria. Since the early 2000s, there has been a boom in new cultural and literary spaces in the city, accompanied by a division between public sector and 'independent' scenes, each with their accompanying aesthetic styles (discussed in Chapter 2). Hamdy and his friends were part of the NGO-isation wave. Throughout the 2010s, Hamdy was the director of the Eskenderella Association, which took as its task the documentation and revival of the city's urban history and memory, and which organised an annual festival in memory of the composer and singer Sayed Darwish (1892-1923) in his native quarter Kom El-Dikka.

Hamdy's career, from experimental young poet to NGO functionary, in combination with the literary shift from committed grand narratives to individualistic everyday observations, might be read as a neoliberal process of depoliticisation and privatisation. But in autumn 2011 in the wake of the 25 January revolution, things looked different. New spaces were opening and events being organised, and they usually gained good audiences. There was a spirit of opening and possibility, albeit anxious and precarious. As part of the fieldwork that Mukhtar and I had just begun, we were attending exhibitions and symposia in El Cabina, an independent cultural space that had opened months earlier. During the five years of its existence (2011-2016), El Cabina quickly developed into a meeting place for an internationally connected, politically pro-revolution, leftist or liberal or secular cultural milieu with distinctive avant-garde tastes.

On two occasions, Hamdy was involved. The first was a photo exhibition of private photographs collected by Maher Sherif (see Chapter 2), a writer and book artist of Nubian origin and along with Hamdy a founding member of the Eskenderella Association (later, their paths parted). The exhibition, titled 'Albi album (My heart is an album), presented family photos, mostly from the 1950s and the 1960s. The audience's attention was seized by photographs of women in fashionable swimming suits on the public beaches on the seafront of the city - something that today, after decades of Islamic revival, is only possible on socially exclusive private beaches. For the people who came to the opening, these images from 'the age of the swimsuit' offered a site to imagine a free, untroubled time before the Islamic revival with its gendered anxiety, a time when Egypt looked like a modern country much more than it does today (see also Ryzova 2014).

Looking at these images today, it is easy to forget that they mainly show the Egyptian urban bourgeoisie of the 1950s and, at best, the upwardly mobile urban inhabitants of the 1960s. Egyptian villagers lived under harsher material conditions than today (Abaza 2013). Daughters of city-dwellers may be more conservative today regarding their beach attire, but daughters of villagers have wider access to education, and are less likely to get married at the onset of puberty. 
Nostalgia for the era of the swimsuit neutralises the history of class inequalities, many of which continued throughout the Nasser era despite its significant social mobility.

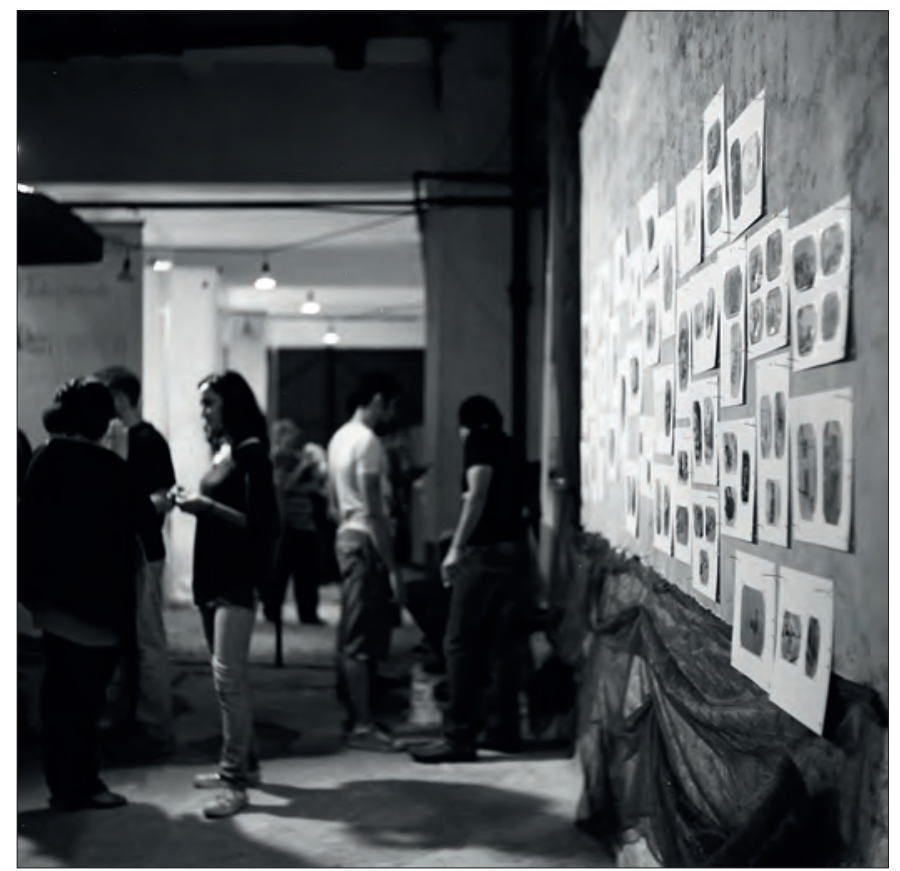

Image 19: Opening of the 'Albi Album exhibition, El Cabina, 23 October 2011.

In a discussion during the opening, Hamdy argued that it was important to keep this memory alive but to remember that it was not a perfect time either. The nostalgia invested in such images, he pointed out, hides class society and poverty, and the foreign domination of Egypt before 1952. This critical note notwithstanding, Hamdy emphasised that the old Alexandria was something that needed to be preserved, remembered, and revived - with an awareness of its contradictions.

This was a point he made even more clearly at a symposium dedicated to his poetry that took place in El Cabina on 17 October 2011. Connecting the memory of his youth and childhood with his free-verse poetry in colloquial Egyptian Arabic, Hamdy outlined his literary and political vision of the city:

I'm interested in the study of Alexandria as an example of the human condition that we live everywhere in the world - an example of pluralism, openness, tolerance. [...] Alexandria, starting with Alexander the Great, is a sentence that has no full stop, no definite end... 
The real Alexandria for Hamdy was not the bourgeois and cosmopolitan districts on the sea, but the old popular quarters housing migrants from different parts of Egypt, living together in close spaces, but feeling that the whole city is theirs. It was this city - very much the city of his childhood, still remembering the colonial era, connected to a history and looking forward to a better future, rooted yet tolerant and open-minded - that Hamdy elevated to a moral principle that must live on, despite and against the powers that have since come to dominate the city. Hamdy's vision of the city did not exclude contradictions and conflicts, but he was convinced that twentieth-century popular-quarter Alexandria offered constructive solutions towards coexistence in spite of those contradictions, and therefore needed to be preserved, remembered, and revived.

Locating the myth of cosmopolitan Alexandria as an open city (in the sense of being open to the world and to difference) in its old popular quarters stands in a longer literary tradition that was established by Edward Kharrat $(1993,1999)$ and other Arabic writers (see Kararah 2006; Starr 2009; Halim 2013) before Hamdy's time. It is also reflected in M.'s appreciation of Bahary as the real Alexandria (although he is not a writer and reads little). According to Hala Halim (2013: 282-283), Arabic writing from Alexandria has developed the theme of Alexandrian cosmopolitanism in a decidedly different fashion than that adopted by most European writers, and at times even decidedly against it. But as Alaa Khaled (2012: 12-13) points out, even while that tradition locates cosmopolitan coexistence in popular quarters, it remains committed to the politically safe vision of a lost paradise, grounded in a sense of perpetual loss between a grim present and a golden past.

For Hamdy, a key theme in his vision is the relationship with the Other, especially the Christian and the foreigner. That relationship is at once fraught and attractive, as in his poem White desire (Raghba bida, Zidan 2013):

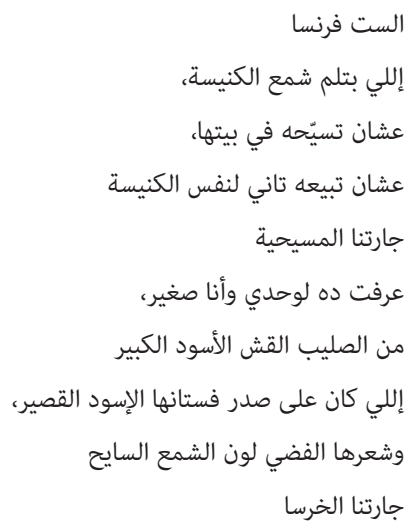




$$
\text { صرخت لما الشمع المغلي اتكبّ عليها }
$$

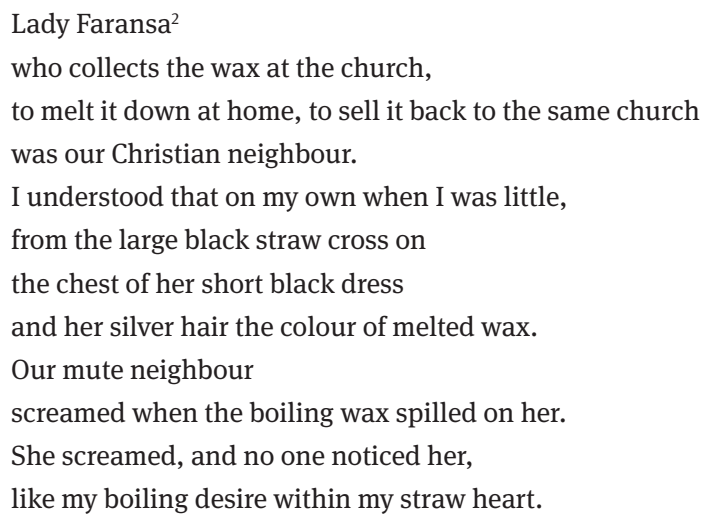

I noticed a peculiar turning of tables regarding heritage and progress in these events. They took place in a cultural milieu that sees itself as progressive and in opposition to both a conservative religious current as well as the authoritarian system of the state. The prevailing tone was that of a cultural critique of the forgetfulness and destruction of history involved in the Islamic revival. A selfdeclared cultural and literary avant-garde was upholding remembrance of the past and connectivity with tradition, in opposition to a wave of religiosity marked by a characteristically modernist oblivion in place of history.

A claim to a tradition involves a claim to power. As Talal Asad (2014) has pointed out, traditions are not taken-for-granted continuities. Rather, they are the foundation and result of struggles for power to define, reproduce, and guard them. Hamdy's myth of Alexandria as a principle of openness located in Ghurbal rather than in the seaside districts is a way to wrestle some of the power of the cosmopolitan myth from the European bourgeois into Egyptian working-class hands. And yet it remains grounded in a specific, essentialised vision of what is and what is not Alexandria, and an accompanying claim by the urban intelligentsia to define the city. Although depicted by him as a principle of openness, Hamdy's Alexandria is not open in every direction.

2 Faransa, Arabic for France, was common as a Christian girl's name in the early twentieth century. 


\section{Abu Kharouf}

A long discussion followed at the symposium. Among those asking questions was Mukhtar. He has a different relationship with the city: 'Maybe it is because I only moved to Alexandria seven or eight years ago, and I don't love it the same way.' He asked why the Alexandrian authors in the circle only write about the old Alexandria. He demanded a literature for and about the districts that were once small houses and gardens, and have now turned into 'a concrete jungle': El Mandara, 45 Street, Abu Kharouf. Mukhtar claimed that these places are never mentioned in the stories of the city, but that they are even sharper and harsher places than some of the ill-famed old quarters such as Gheit El Enab (for the latter, see Abdel Meguid 1999; Eltoukhy 2014). They, Mukhtar argued, are places that can and must be written about: 'Abu Kharouf can equal the Gammaliya of Naguib Mahfouz.'

Mukhtar was in this way claiming space for his own writing. At the time, he was sketching a novel (Shehata 2017) that would be located partly in Abu Kharouf and partly in Gheit El Enab.

Hamdy disagreed. He had actually lived in Abu Kharouf for more than ten years. There are writers from the bourgeois milieu who really do not know this side of Alexandria, but Hamdy knows it inside out. He argued that those suburbs are like a cancer attacking the city. In contrast to the plurality, openness, and rootedness that he identified as the characteristics of Mahfouz's Gammaliya (and his Ghurbal), Hamdy saw informal settlements such as Abu Kharouf as the very opposite of the idea of Alexandria. He claimed that they are 'like Kandahar' (drawing a comparison between the Taliban stronghold in Afghanistan and the power of the Salafi movement in Abu Kharouf), a place where social relations have collapsed, embodied by adolescents from the informal areas who come to fill Raml Station during the Islamic feasts to harass women and anybody who looks unusual.

If for Hamdy Alexandria was a dream of a better world, a memory to revive for the sake of a better future, for Mukhtar Alexandria was the shocking reality of a divided city in which some people attempt to revive the city's cosmopolitan age, while others want to transform it into Kandahar, a seaside city in which some people living in inland informal settlements have allegedly never seen the sea. After the reading in Cabina in 2011, he criticised the downtown intellectuals for the self-imposed isolation they create by celebrating the memory of old Alexandria and rejecting the concrete jungle. Doing so, he argued to me, they close themselves up in a small circle and, by rejecting the reality of the city, fail to reach out to the concrete jungle.

This is the Alexandria Mukhtar moved to in 2004, at the age of thirty: a government school in Abu Kharouf, a poor area with a large Christian minority, reputed to have high levels of crime and strongly influenced by the Salafi move- 
ment. With his family (he was recently married), he moved to a small apartment in Asafra on the poorer, inland side of the railway line, and some years later to El Mandara further east, also on the poor side of the railway line but closer to the seafront and the upmarket areas, and better connected with public transportation. He did not move to Alexandria of his own accord. Born to a family of fishermen in a village in the northern Nile Delta, he lived for a short time in Cairo after his studies, then worked as a teacher in his village and later in Borg El-Arab. From there he was transferred to eastern Alexandria in 2004. For many years, Cairo was the city where he really wanted to live, and Alexandria as a whole was his anti-city.

In this time, Mukhtar wrote his first novel No to Alexandria (Shehata 2010). A psychological novel in the guise of a spy story, it tells of Sa id (Arabic for 'happy'), a deeply unhappy man who establishes himself in Asafra in Alexandria but leaves it for Saudi Arabia as a migrant worker, then Afghanistan as a member of al-Qa'ida, and eventually Germany where his only true friends are spies set after him by various intelligence agencies. It is a story of many illusions, and Alexandria appears in it as a projection rather than a real city. In Mukhtar's home village, poor people go to public hospitals in Alexandria when they are seriously ill, which is why Alexandria is known as a city of no return, the city where one dies. For Sa id, the main character in the novel, Alexandria is a city of no return because it is associated with memories so painful that he cannot live with them. It is not a dream, not a value to revive, but a dull reality of rural to urban migration mixed with nightmarish imaginaries of death and madness. Notably, it is located in the 'concrete jungle' of Asafra and Abu Kharouf.

In November 2014, shortly after Mukhtar had resumed work on his third novel (Shehata 2017), we took a walk through the alleys of Abu Kharouf where the novel is set. He knows the area well but told me that he never felt comfortable or safe there. He added that because he does not like the place, he was able to write about its contradictions and ambiguities, to describe and understand it in a way he could not do about his own village and family (the glorified subject of his 2013 novel The Migration of the Sons of Saber). The Abu Kharouf of his third novel, narrated between the recent past and the near future, is divided along confessional and class lines. In the near future of the novel, Christians and Muslims live in confessionally segregated compounds. Only the poorest are compelled to mingle. It is just fear and hatred that sometimes unite the divided inhabitants of the ugly face of the city. Relationships across lines of class and confession that form the narrative thread of the novel do not create a vision of openness and tolerance, but rather tell of love and friendship as something precious and exceptional in a world that actually does not allow such exceptions. 


\section{The house of Cavafy}

The seaside myth of Euro-cosmopolitan Alexandria (which remains the hegemonic myth of the city) is also a story of living with difference. It tells a version of the narrative of a city open to the world and difference that highlights the character of the khawaga, Egyptian Arabic term for a non-Muslim European living in Egypt (Awad and Hamouda 2006; Mabro 2006). The khawaga is an ambiguous figure in Egypt, uniting post-colonial power, nationalist paranoia, tourist business, and a romanticised memory of social coexistence in the early twentieth century. The khawaga has lent his (male gendered) figure to the concept of 'the khawaga complex' ('uqdat al-khawaga), which describes the characteristically post-colonial relation of hegemony where people of Western origin are taken more seriously and treated with more respect, whether they deserve it or not. As time has passed, the Greek and Italian khawaga especially (who are not colonisers like the Englishman and not an enemy like the Jew, and who are culturally a bit more like 'us') have become socially more marginalised and at the same time increasingly sympathetic and interesting as literary characters (e.g. Sherif 2013; Hamed 2014).

In the 1990s, the circle of young writers around Khamasin developed an interest in the history of non-Arabic literature from Alexandria. Late nineteenth- and early twentieth-century Alexandria had been home to many writers in Greek, Italian, and English. The most famous of them was the Greek poet Constantin Cavafy (Konstantinos Kavafis, 1863-1933) who lived most of his life in Alexandria. Today, his apartment near Nabi Danyal Street is a museum. He is well known in literary circles, and recently a graphic novel dedicated to his life was released in Arabic (Koraiem and Hamed 2015). Back in the 1990s, Hamdy Zidan and Khaled Raouf (who later became a theatre director and a translator of Greek literature into Arabic) were just beginning to discover Cavafy's traces in Alexandria. Trying to find his old home, they entered a nineteenth-century apartment building (later, it turned out that it was the house where Cavafy was born, not where he lived during his adult life). The inhabitants asked whom they were looking for. The young men explained that they were looking for the house of the poet Kafafis (Arabic pronunciation of Greek Kavafis), and were told that nobody with that name lived there. The poet was long dead, the young intellectuals explained. 'Why are you looking for him if he's dead?' the residents wondered with increasing suspicion. A woman mistook Kafafis for kafatis, a derogatory slang term for Christians: 'There are no kafatis here! Get out of here you kafatis, you thieves!'

Forty years after most of the khawagas of old had moved out of the city, the search for Cavafy resulted in a comic misunderstanding that is telling of the changing times. The experience and problem of difference in Alexandria today only has a little to do with the khawaga. Instead, it is more closely related to tensions 
between Muslims and Christians, Egyptians and Syrians, old and new migrants to the city, different religious movements and ways of life, well-off and poor people, old and new bourgeoisies, military and civilians, and political polarisation. In this network of contemporary divisions of the city, the evocation of cosmopolitan Alexandria - especially its seaside Euro-cosmopolitan variety, but also its inland old popular quarter variety - can be a gesture of closure against all those people and ways of life that contest and compete with the liberal and cosmopolitan urban utopia.

Cosmopolitan Alexandria is a very likeable myth, and there are good reasons why it is reproduced by writers who hope that their city might be more accommodating towards different ways of life - especially those that are not promoted by the Islamic revival or the real estate boom. Such ways of life are indeed precarious in Alexandria outside some protected niches. However, this is not an innocent myth. It comes with a political economy. It easily legitimates the privileges of the urban bourgeoisie and the Egyptian regime. It also allows European funding agencies and visitors to leave unchallenged the comfortable privileges they enjoy. This makes it a safe (and thus also potentially profitable) topic for national projects and international cooperation alike.

As a result, the myths of the city in this tradition have become populated by two kinds of strangers: those who fit into a vision of openness, and those who must be excluded, even destroyed, in order to safeguard that openness. It is no coincidence that many (albeit not all) people who sympathised with the cosmopolitan coexistence narrative joined forces in 2013 with militarist nationalism, and either tacitly accepted or openly supported the massacring of supporters of the deposed president Morsi. With their vision of moral and confessional purity and their strong grounding in popular neighbourhoods such as Abu Kharouf, the Islamists are easy to depict as the very opposite of the spirit of Alexandria as Hamdy sketched it. Seen from this point of view, they were the ideology of the anti-city, and they had to be excluded and destroyed.

\section{The East of the City}

The anti-city of the cosmopolitan myth, however, actually makes up most of the city. Alexandria as I have encountered it in the past years is a plural city, but not a pluralistic one. Hamdy's version of the real Alexandria as rooted in and open to difference, continuous between past and present, strikes me as more sympathetic, but I find Mukhar's version, which foregrounds the 'concrete jungle' and the break with the past it involves, closer to the city I know. 
While public-sector cultural flagships including the Bibliotheca Alexandrina have engaged in nostalgic celebration of 'cosmopolitan Alexandria' (Awad and Hamouda 2006), a certain anti-nostalgic backlash has emerged in parts of the cultural scene. Interestingly, this backlash has been produced partly by the very same people who, twenty years earlier, spearheaded the attempt to reconnect their urban present with its past non-Arabic inhabitants and literatures (e.g. Raouf 2016). Paradoxically enough, it is being articulated by people who are internationally well connected and who read both English and Arabic literature and social theory (and some read French) - that is, people who would easily qualify as cosmopolitan on most counts.

Among them is Ali Al-Adawy, born in 1985 in the eastern suburb of Abu Qir, organiser of film and cultural programmes, writer and editor. Between 2014 and 2016, he and some of his friends were working to put together a research and film project about the East of the City (Sharq al-madina), which, in their view, has replaced the historical downtown of al-Manshiya and Raml Station as the centre of the city. The East of the City - especially the district of Sidi Bishr - represents an anonymous, consumerist, at once conservative and individualist form of urbanity influenced by Egyptian migration to the Gulf, the import-export business, the Islamic revival, and unrestrained real estate expansion. If the old central districts stand for what Alexandria may once have been, Sidi Bishr shows what it is now becoming, and quite literally so: the race to demolish villas and smaller apartment buildings and to build fifteen-storey high-rises in their place began in the East of the City around the turn of the millennium.

Since 2011, this demolition and construction boom has engulfed almost the entire city. Old popular quarters such as Bahary, Ghurbal, and others have been thoroughly transformed, a large portion of their older houses replaced by high-rises. In 2019 and 2020, the boom was brought to a temporary halt by heavyhanded government measures against private contractors (Morsi 2020). However, this has not stopped the gradual disappearance of the seafront. Beaches have applied admission costs for some time, following two decades of privatisation of public space. Until recently, however, viewing the sea had still been free of charge. Recently, exclusive public-private-partnered new projects on landfills are moving further east along the coast every year, making the sea increasingly inaccessible to the general public, since it is no longer visible from many parts of the Corniche (El Nemr 2017; HCCSR 2019).

Some urban activists try to document and protect urban architectural heritage. But with military, government, and private institutions competing towards generating maximum profit from construction and real estate, a progressive erasure of the city appears unstoppable. And with the gradual disappearance of 
the sea shore behind resorts on landfill, Alexandria may one day no longer be a city by the sea for its non-privileged inhabitants.

In search of ways to overcome what he sees as an unproductive nostalgia in writing about the city, Ali turned to the work of Walter Benjamin. With funding from the Goethe Institut, he organised a workshop about 'Benjamin and the City'. Ali hoped that Benjamin's way of writing about Paris and Berlin (Benjamin 1991a, 1991b) might provide guidance for overcoming the cosmopolitan nostalgia, and for deconstructing any and all narratives of the city:

The notion of the narrative of the city - be it an old and conservative narrative, or a contemporary one - is an ideological notion that constantly relies on the historical, political, social, and economic framework and context. It expresses the reality that it in a way produced despite all its attempts to disguise it. (Al-Adawy et al. 2016: 6)

The main outcome of the workshop was a small collection of essays that was presented in El Cabina on 10 March 2016. It was more contradictory than Ali might have been aiming for. The texts were evenly divided between two approaches: Abdelrehim Youssef, a teacher, poet, and cultural programmer at El Cabina, and Yasmine Hussein, a researcher at the Alexandria Library and photographer, had each written childhood memories with an eye for minute details and personal experiences, inspired by 'the dominance of the poetic' (in the words of Abdelrehim) in Benjamin's Berlin Childhood around 1900. Hager Saleh, a translator and MA student in history, and Hakim AbdelNaim, an actor and theatre director, produced more comprehensive critical engagements with the city. An expression that came up in the latter two texts was al-madina al-za'ila, 'the perishing/nonpermanent city', a vision of a city in a constant process of erasure. In the words of Hager Saleh:

Thus, the city likes to show off its passing/perishing ( $z a^{\prime}$ 'ila) cosmopolitanism. It hides its history and covers it with dust as if it were a disgrace that deserves to be erased, and then again boasts of it with insolence. The city persistently reinvents itself, carrying a new face in every era and hiding its old face under rubble. (Saleh 2016: 10)

A long discussion followed the presentation. Although it had not been a major theme of the workshop, a controversy about 'nostalgia or not' dominated the discussion.

The theatre director and manager of a performing arts NGO Ahmed Saleh claimed: 'Also today's writings were loaded with nostalgia, just like the writings of the past twenty years. What new does Benjamin offer?' Abdelrehim disagreed and pointed out that three of the five texts presented were critical of nostalgia; only his and Yasmine's leaned towards it. Hakim commented that Ahmed pro- 
bably intentionally played the role of the provocateur. More important than nostalgia or not, he went on, was to question the classist aspirations of the specific nostalgia for a city by the sea. From what kind of societal configuration did that city emerge?

The poet and guest participant in the workshop Ahmed Abdel Gabbar defended a nostalgic relatedness to the past and its traces:

Cavafy also didn't write of Alexandria of his age, but of the Hellenic era. That history is still present, under the earth. Kharrat's popular quarters and Durrell's Cecil Hotel are still there in the city you move in. While I speak, I see the ruins of the demolished Rialto Cinema. But it was there. Even if only in the layout of the streets, the traces remain with us. I see nostalgia positively, if it means that I know what I write about.

Hager countered: 'We are drawn to cosmopolitan longing because of its dramatic touch. Like classical tragedy, it is attractive.' Addressing the many historical periods of the city and its varying centres and dominant groups, she pointed out that the location of the city itself was constantly on the move: 'The city is not something solid.'

Mohamed Elshahed, editor of the Cairobserver magazine on urbanity and architecture in Egypt, insisted on a more complex picture. The way we speak about the past reflects the way we speak about the present and reproduces its blind spots, he argued. What is left out in the binary of the khawagas (as in Durrell) and the popular quarters (as in Kharrat), he argued, is the social history of Alexandria from the 1940s to 1960s, a period of major social mobility for urban inhabitants of Egyptian origin, when many rural migrants climbed into bourgeois society.

Abdelaziz ElSebaei, one of the founders of the Eskenderella Association who had left it in 2013 along with Maher Sharef, intervened to problematise what he called 'the passion for the city':

It has become a sort of national disease. I'm not against engagement with the city. But we always try to reach back to times before us. Myself, I'm not as upset today as I was twenty years ago when an old house is demolished.

The presentation of the Benjamin workshop in March 2016 marked a departure from the nostalgic tone that had dominated the poetry symposium in 2011. Svetlana Boym (2001) argues that nostalgia may come in restorative and reflective varieties; and Ahmed Abdel Gabbar clearly claimed the contemporary usefulness of a reflective nostalgia in his comment. The critique of cosmopolitan nostalgia, however, equates it with a futile attempt to restore something that can no longer be retrieved, and probably was never really so beautiful in the first place. Such 
critique is in line with an emerging shift from the binary towards the fragmentary in writings about the city, such as in Alaa Khaled's Alexandrian Faces (2012). The Benjamin workshop also coincided with other cultural events and publications in 2016 that balanced a reflective-nostalgic search for ways to remain connected to the city's twentieth-century history and the positive values it might represent on the one hand, with a demand to recognise the self-erasing, conflicted, and divided character of the city's present and past on the other. Events we attended included a history workshop curated by Aliaa Mosallam that highlighted social conflicts and radical politics in the early twentieth century (Nizar 2016), and a public debate on the curse and possible uses of nostalgia organised by Amro Ali in 2016.

What had changed? A generational shift is part of the story. Some participants in the Benjamin workshop, notably Hager Saleh and Hakim AbdelNaim, were young enough to have experienced their generational formation during the revolutionary period. But others had been active in the scene even before 2011; Abdelaziz ElSebaei was born in 1949. Nostalgia in all varieties is a reflection of the present against which it is posited, and the present had changed. For those who in 2016 questioned the nostalgia for old Alexandria, the recent events of the revolution provided a more pertinent nostalgic relation to the present. Theirs was now a more conflicted and combative longing for a future very recently lost, and the myth of an unchanging spirit of a true Alexandria appeared less helpful for providing orientation in the city and country in which they lived. By 2016, after a defeated revolution and a victorious construction boom, the topos of unsolved conflicts and permanent erasure had become more pertinent, and the nostalgic vision of connectedness and openness more difficult to maintain for some people (Faruq 2017).

In a short essay published a year later, Hakim AbdelNaim made explicit the link between his suspicion towards nostalgia and the trauma of the defeated revolution:

All places are accompanied by trauma, by post-traumatic stress disorder, by an enormous affective experience that was not completed, that found no occasion to have a light ending, or even a heavy one but without a sudden cut, as if a person dies burning and remains in his final state, state of trauma... and who knows if he died of trauma or of heat? I detest longing and everything that has a relation with longing and everything that makes me feel that it is part of the longing I detest. I fear it and its closed circle. (AbdelNaim 2017)

And yet the critical rethinking of the city and its myths also shows remarkable continuities - personal, institutional, and thematic alike. The essays of the Benjamin workshop were published in the Tara al-Bahr magazine dedicated to literary, historical, and theoretical reflections about Alexandria. It was edited by some 
of those who were present at the Walter Benjamin workshop - and mostly read by people in the same circles. Its authors include Khaled Raouf, Maher Sherif, and others, all of whom had previously played a major role in the literary rediscovery of non-Arabic Alexandria. It was made possible by a European grant for three issues (which the editors stretched to make four), and while it did not serve the Euro-cosmopolitan myth, it did converge with a donor interest in cities and urbanity. The same magazine also published the text just quoted by Hakim Abdel Naim - and the Arabic translation of an earlier version of this chapter (Schielke 2016a).

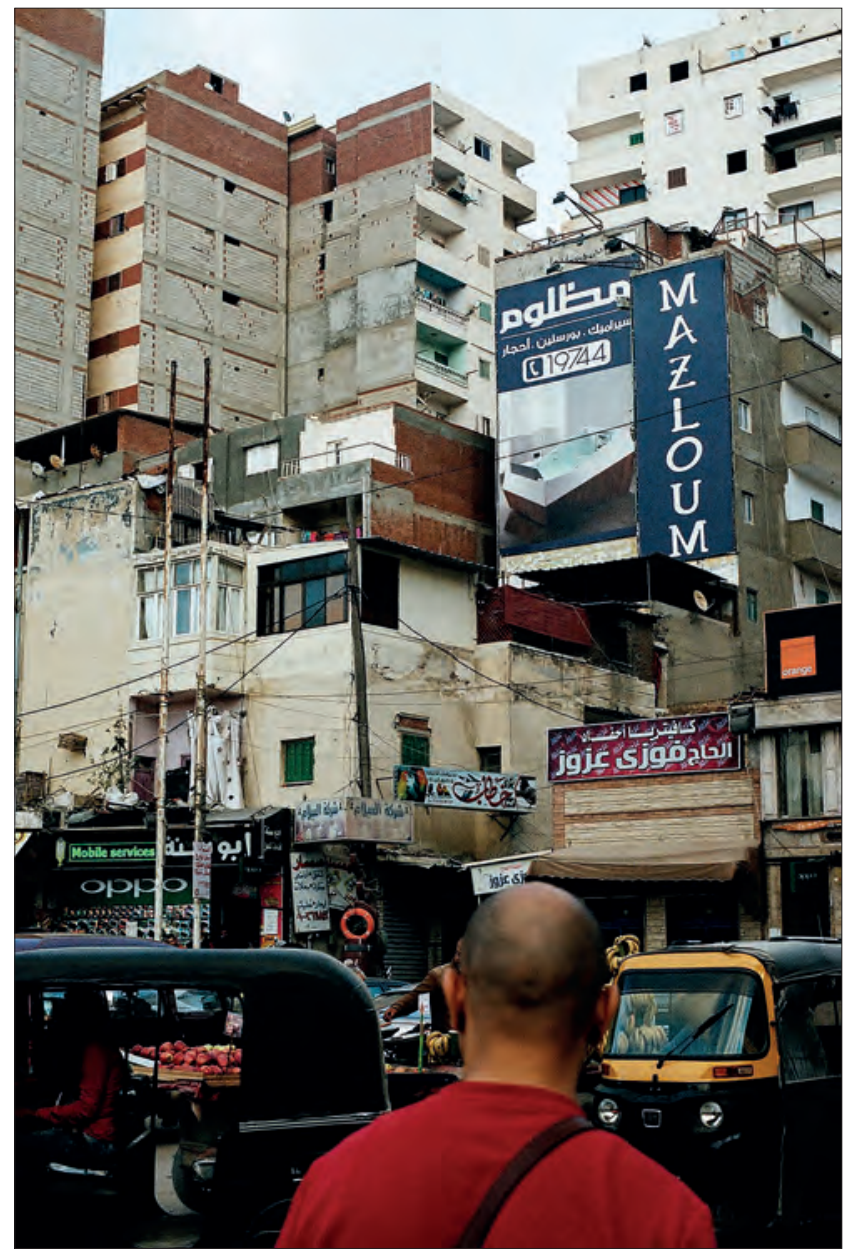

Image 20: Entrance to Mallaha Street in inland El Mandara, East of the City, March 2016. 
Like Alaa Khaled's literary work and Aliaa El Mosallam's history workshops, Tara al-Bahr is also consciously aimed at producing a complex rather than a binary vision of the city. And yet by the virtue of its intensive concern with the city as its primary topic and focus, it, too, contributes to the mythologisation of Alexandria. It is a different myth, however. It tells of Alexandria as a perishing, non-permanent city of conflicts, fragmentation, and erasure.

The myth of the non-permanent city has the paradoxical advantage over the myth of the cosmopolitan city that it is more inclusive. It has space for both alManshiya and Sidi Bishr, both Bahary and the Chinese Housing. The myth of the non-permanent city is cosmopolitan in its own way, in the sense that it tells of the urban coexistence of difference. However, it highlights conflicts over harmony. I am definitely not impartial in this matter. Part of a wider shift in academic interest towards understanding Alexandria as an ordinary city in the present (El Chazli 2018; Jyrkiäinen 2019), this chapter and this book contribute to the narrative that highlights conflicts and erasure. With the publication of the Arabic version of this chapter in December 2016, it became a part of the conversation it addresses (see Tara al-Bahr 2017). And yet the issue at hand is not an opposition between a romantic fantasy of what Alexandria might once have been and a realistic recognition of what the city really is. The very question of what or where the city 'really' is is an exercise in fantasy.

Every claim to have located the city is the product of a certain politically and morally loaded work of imagination (Chiti 2016). Hamdy's rewriting of the cosmopolitan myth from the point of view of Ghurbal, Mukhtar's emphasis on the 'concrete jungle' of Abu Kharouf, even Ali's search to deconstruct the narrative unilinearity of 'the city' are all expressions and draft blueprints of specific urban mythologies where neighbourhoods, streets, and fictional characters embody specific affective, political, and moral visions and conflicts.

\section{The Chinese Housing, once more}

In June 2016, Omayma Abdelshafy, one of the editors of Tara al-Bahr magazine in which the essays of the Benjamin workshop had been published, reflected about the intertwining of telling of the city and imagining what it might be, in a free-verse poem she published on social media (reproduced here with my translation): 


$$
\begin{aligned}
& \text { إسكندرية } \\
& \text { الخيالية } \\
& \text { التي لا توجد إلا في أوهامنا الصافية } \\
& \text { تنتظرني } \\
& \text { هناك } \\
& \text { وفي قلبها نقطة واحدة من الحقيقة } \\
& \text { أحبها } \\
& \text { وأحن للعودة إليها } \\
& \text { ليس للإسكندرية فضل فيها } \\
& \text { لكنني تركتها هناك لك لكند } \\
& \text { حتى لا تنقطع صلتي بالمدينة } \\
& \text { التي كنت أعتبرها امي أحيانا } \\
& \text { لأنني غبية بما فيه الكفاية } \\
& \text { لأكون ابنة لمدينة لم تُحك بعد بـ لمداية } \\
& \text { فقط } \\
& \text { هي تتكون بالكامل من أحلام خالصة } \\
& \text { وأساطير معقدة } \\
& \text { تنافس الكثيرون لصناعتها } \\
& \text { بخيال فقير } \\
& \text { يليق بكل جمالها. }
\end{aligned}
$$

\footnotetext{
Alexandria

the imaginary one

that only exists in our pure illusions

is waiting for me

over there

in its heart a single drop of truth

I love it

and long for return to it

Alexandria has no power over it

but I left it there

so that I may not lose touch with the city

that I sometimes considered my mother

because I am stupid enough

to be the daughter of a city not yet told

Only

it is made up entirely of immaculate dreams
} 
and complex myths

Many compete to craft it

with poor fantasy

that suits all its beauty.

In the discussion following the Benjamin workshop in March 2016, Amro Ali had suggested that 'the curse of Alexandria is that it's more powerful in imagination'. But what is the thrust of that imagination? Is it one of a 'crippling nostalgia' as Amro called it, or is there space for a forward-looking dreaming? In the final comment to the discussion, Mohamed Elshahed called for 'a nostalgia for the future, a radical vision. We live in a fascist era, so let's long for the future.'

Future is a tricky thing in Alexandria, however. If carbon emissions continue anywhere near the current rate and climate change goes on as predicted, large parts of the city will be submerged owing to rising sea levels by the end of the twenty-first century (Link et al. 2013; Stanley and Clemente 2017; Gebremichael et al. 2018). The parts of the city that are closest to the sea are higher and will be less affected, but most of the inland sub-urban crescent is built on former lakes and marshes, and will become uninhabitable. Alexandria will again be a city by the sea, but it will hardly be a beautiful sight. The future-oriented question about Alexandria is thus far more radical than the one debated at the meetings in El Cabina between 2011 and 2016.

The news about the next, perhaps most catastrophic, erasure in the long history of Alexandria's erasures is beginning to reach the city's inhabitants, thanks to dramatic online visualisations that show the vast stretches of land likely to be submerged and popular science television documentaries that list Alexandria as one of the cities likely to disappear in the near future. This issue was at the heart of a symposium on science fiction at the Writers' Union on 16 November 2019.

Gamal Kashhat opened the symposium by sketching the plot of the novel he was working on. This imagined what would happen if humans knew the date of their death, uniting science fiction with Islamic moral and eschatological imagination in an intriguing way. But his main concern was more mundane. He proceeded with a lecture outlining major names of Anglophone science fiction from the twentieth century, and emphasising the role of fiction in paving the way for scientific innovation. At the end of his talk, he showed a popular science documentary that showed, in rapid and dramatic succession, ten major cities likely to disappear soon. Among them was Alexandria. Gamal Kashhat concluded by calling for a kind of science fiction writing that could imagine ways to rescue Alexandria and the Nile Delta from sea level rise. Imagination and fiction, he proposed, could pave the way for scientific solutions, and therefore such science fiction - which 
was yet to be written - needed to be brought to the attention of those in positions of responsibility, if possible even the President of the Republic. In the discussion that followed, there was an almost unanimous agreement on the urgency and necessity of such a pedagogical mission for science fiction to save the city.

A longing for the future echoes Ernst Bloch's (1980) 'concrete utopias': visions of a better world that include a plan of action or at least an expectation that they can be reached. For Bloch, Marxism provided the one true concrete utopia to strive for. For those who had gathered at the Writers' Union in 2019, the concrete utopia they sought to imagine was more of an engineering kind.

There is no agreement among Alexandrian writers I know whether crafting concrete utopias of the future is literature's task. Among those closer to the tradition of conservative modernism who tend to gather at the Writers' Union it may be. But even for them it is a contentious issue (as we saw in Chapter 4, where poets debated whether poetry can change the world). Writers active in circles of the downtown independent milieu such as those that gathered at El Cabina, in contrast, have shown more concern for critique and alternative ways of life in the present than for utopian visions for the future. Their concrete utopias appear to be either located in a nostalgic past or they are inspired by the transient utopian moment of the revolutionary uprising that in itself was a better world, even if it failed to change the future of the country. Their literary future visions, in contrast, tend to be a rather grim continuity of the present (Eltoukhy 2014; Shehata 2017), connected with a trend among some internationally recognised Egyptian writers that has been labelled ‘dystopian fiction' (e.g. Towfik 2011; Eltoukhy 2014; Naji 2015; Rabie 2016) by Anglophone critics (e.g. Alter 2016). ${ }^{3}$

Utopias portraying a bright future are today more associated with the right, be they militarist nationalist fantasies of grandeur or Islamist promises of a moral society on the path to Paradise after death (each also having its own nostalgic past). Some of the concrete utopias that the Egyptian regime propagates, in the shape of nationalist prestige projects and new cities, including a new administrative capital, are all too similar to dystopian fictions of a country divided between secluded rich suburbs and an urban hell (Towfik 2011). They only promise a better future for the better off.

3 According to Nael Eltoukhy (2019), 'dystopian fiction' is not a self-chosen label, and he does not think of his work as dystopian. Rather, the label reflects a Western literary taste for a style, and for themes that have become quickly successful among non-Arabic readers and tend to be translated swiftly. Compared with the nostalgia for the Euro-cosmopolitan era among many Egyptian and foreign readers alike, this tells of an interesting shift in the interests and expectations of some non-Arabic readers. 
Perhaps the question needs to be posed differently. Just as the sincere search for a concrete utopia by means of literature should not be mistaken for being naive, engagement with a contradictory present without a golden past or glorious future should not be mistaken for being nihilistic. Instead, its concrete utopias are located in space rather than in time, its moral striving focused on the possibility of alternative and parallel lives rather than a wholesale reform of society.

Omaima Abdelshafy's imaginary parallel Alexandria was remarkably devoid of details: a critical companion to the materially existing Alexandria rather than a vision of what it could be. The power of literary imagination of this kind is not to produce daydreams, but to give reality a twist. And while one should view utopias critically, one needs to be cautious about urban dystopias as well (Robinson 2010). There are also other useful visions around.

The Chinese Housing is built on a hill. It may be demolished one day, but it will not be submerged. In spring 2016, I went there again to visit M. He had made some progress. Since business in his original trade was bad and no improvement was in sight, he had opened a shop for household goods as the junior partner of a local trader. Business was acceptable, and he was feeling more at home than ever in the Chinese Housing; and yet he was disillusioned. He had put faith in the revolution in 2011, and voted for Islamist politicians in the elections that followed. In 2013, he had put faith in the military, which he by then considered the only institution that could lead the country. In 2016, he was positive that nothing had changed, and doubted whether any change could be expected in the near future.

M., along with millions of others, is part of today's Alexandria. He is a rural to urban migrant who built a house in an informal settlement. Although he sympathises with the Salafi movement and their vision of purity, he does not live that way. He says that in practice, the best he can do is approximately follow the right path without completely losing sight of it. $M$. is a conservative man who at the same time is open and attentive to different people and ideas. He has a strong entrepreneurial spirit, and is constantly in search for new opportunities. Despite living in what constitutes the anti-city for those who hold to the dream of cosmopolitan Alexandria, many of the values and attitudes he embodies are not so different from those held by the inhabitants of the mythological cosmopolitan city. He is subject to the powers that are transforming the city, but he is also crafting it towards his needs and values. He reminds us there is still more to tell about Alexandria.

Rather than dreaming of the Alexandria that might be, M. has been trying to imagine, in more pragmatic vein, what he may realise for himself and his family. He finds it difficult to imagine how things might change for the better. Repeatedly expressing the desire to migrate to the United States with his family to offer his 
daughter a better future, he has been submitting an application for the green card lottery every year; but he also appreciates the opportunities he has been able to find around him.

The next time I met M. in autumn 2016, I showed him the Arabic translation of an earlier version of this chapter to check whether I had quoted him correctly and whether he agreed with the passages. He agreed, and added: 'For me, the Chinese Housing was like America.' He explained that when he moved to the area he did not like it much, and his wife (who grew up in the East of the City) liked it even less. But he found it full of opportunities and he learned to like it. Manshiya, with its established businesses and networks, was already occupied. It had no space for someone like him with no history and no connections. The Chinese Housing and the surrounding informal neighbourhoods, in contrast, were still becoming, not yet solid, not yet occupied, and therefore a place where one could find and seize opportunities. For M., it carried some of the mythological aura of the American Dream.

What makes M. an interesting theorist of the city is that he does not try to provide an overall theory of 'the city'. Instead, he has a handful of useful theories about different parts of the city, which he appreciates in different ways. His vision of Alexandria is not binary but rather plural, perhaps even pluralist. When asked, he was positive about Bahary being the real, authentic Alexandria. But he appreciates the Chinese Housing, Manshiya, and Bahary each for its own reasons: the first as a space of opportunities, the others as places for business but also for precious weekend outings, time out of the ordinary with his family or friends each with different characteristics and qualities owing to their different shape and history.

Concrete utopias of the true, real city tend to pose and answer the question about where Alexandria is in a binary way. M.'s specific visions of different parts of Alexandria, in contrast, are not utopias but heterotopias, materially existing places that are qualitatively different from others - for better or worse (Foucault 1986; de Boeck and Plissart 2004: 254-258; Ryzova 2015). Heterotopias, too, carry the binary structure of mythology: they are 'other spaces' as opposed to an assumed normal, primary space. But it is a binary where the roles of 'real' and 'anti' are not firmly fixed. The downtown area and the seafront are heterotopias par excellence: areas associated with outings, shopping, a time out of the ordinary - and also counter-normative activities such as drinking in bars (see also Ryzova 2015). As a metaphorical America, also the Chinese Housing has heterotopic qualities - this time juxtaposed to Downtown as an established Old World. In similar way, Mukhtar's and Ali's writings and reflections about the East of the City evoke urban heterotopias that mirror (and are mirrored by) older forms of urbanity that are being erased. And while Hamdy's Ghurbal of his childhood 
and the House of Cavafy (the one where the museum is, not the one from which Hamdy and Khaled were kicked out) can be elevated into embodiments of a concrete utopia of true Alexandria, they could also be regarded as heterotopic sites among others that mark the city's many imaginary locations.

Taking myths seriously as social theories means considering the possibility that some of them may provide a more likely to be true and helpful account of the realities they describe than others do. The essentialising utopias of an organic, true, better city that are evoked by cosmopolitan nostalgia in its popular-quarter and seaside versions alike need to be recognised for what they are: dreams of and strivings for beauty and ease of life, made only more compelling by their increasingly counterfactual character. However, anti-utopian myths of erasure and conflicts can provide a better orientation for understanding what kind of a city Alexandria is today, where it is, and in what directions it is moving.

In the following chapter about writings on walls, I therefore follow the lead of erasure, conflicts, and heterotopic sites, and look at graffiti and its social media avatars as expressions and traces of various ways to live in and claim urban space. 
